\title{
Understanding South Korea's Use of Sports Mega-Events for Domestic, Regional and International Soft Power
}

\author{
Jonathan Grix ${ }^{1, *}$, Joonoh Brian Jeong ${ }^{2}$ and Hyungmin Kim ${ }^{3}[$ \\ 1 Department of Economics, Policy and International Business, Institute of Sport, \\ Manchester Metropolitan University, Manchester M15 6BH, UK \\ 2 Institute of State Governance, Yonsei University, Seoul 03722, Korea; joonoh.j726@gmail.com \\ 3 College of Sport Science, Sungkyunkwan University, Suwon 16419, Korea; feversing@skku.edu \\ * Correspondence: j.grix@MMU.ac.uk
}

check for updates

Citation: Grix, J.; Jeong, J.B.; Kim, H. Understanding South Korea's Use of Sports Mega-Events for Domestic, Regional and International Soft Power. Societies 2021, 11, 144. https: / / doi.org/

10.3390/soc11040144

Academic Editor: Gregor Wolbring

Received: 11 October 2021

Accepted: 24 November 2021

Published: 7 December 2021

Publisher's Note: MDPI stays neutral with regard to jurisdictional claims in published maps and institutional affiliations.

Copyright: (c) 2021 by the authors. Licensee MDPI, Basel, Switzerland. This article is an open access article distributed under the terms and conditions of the Creative Commons Attribution (CC BY) license (https:// creativecommons.org/licenses/by/ $4.0 /)$.

\begin{abstract}
This paper seeks to contribute to the growing literature on 'soft power' by focusing on East Asia as a region gaining in political and economic significance; equally, we highlight the role sports mega-events play in the region's most powerful states' soft power strategies. For the purpose of this paper, we focus on South Korea's soft power strategy and how the hosting of major sporting events has become a central part of this. We introduce both a novel tripartite approach to the study of the motives behind hosting sports mega-events, along with new, empirical data on the chosen case of South Korea. Our findings strengthen the notion that an explanation of why states seek to host major sports events can be better understood by considering the domestic, regional and international dimensions to capture the complexities behind such decisions.
\end{abstract}

Keywords: sports mega-events; soft power; East Asian region; soft power strategies

\section{Introduction}

In recent decades, global institutions, such as the World Trade Organisation, United Nations and the North Atlantic Trade Agreement, have governed the liberal world order, underpinned as they are, by Western norms and values. Three decades on from the collapse of communism in 1990, the world has changed. There are now a number of reasons to believe that the global liberal order, which has served to keep peace for many years, is going through a process of major re-structuring [1]. Commentators point to China's inexorable rise in global affairs, Russia's recent involvement in the war in Syria, the growing strength of the 'Global South', the protectionism exhibited by (now former) US President Donald Trump, the onslaught on the media and spread of so-called 'fake news' as all placing the institutions of old under stress [2]. The dissemination, manipulation and distorting of ideas and ideology through digital data, social media and new technology has grown exponentially alongside the rapid rise of populist politics across a wide geo-political area with new leaders elected in, for example, Hungary, Brazil, the US, Poland, Italy and the Philippines.

Against this backdrop of a 'post-truth' world, states continue to seek international and regional prestige and 'soft power'. The changing nature of international relations after the end of the Cold War and the risk attached to deploying traditional military forms of power (or "hard power") has led to "intangible power resources such as culture, ideology, and institutions" becoming more important in inter-state relations [3] (p. 167). This is not to suggest that states no longer use "hard power", that is, military force or economic sanctions, to achieve what they want, but rather that there is now a greater role for the politics of attraction in international relations than was previously the case. There is also a greater role for different channels of diplomacy, involving such diverse organizations as NGOs, language institutes, universities, and key sporting organizations such as the International Olympic Committee (IOC). Such diplomatic strategies can be conceived as 
what we term a "soft power package:" that is, a collection of soft power strategies that states draw upon usually to appease domestic audiences and strengthen regional and international power positions. This paper seeks to contribute to the growing literature on 'soft power' by focusing on East Asia as a region gaining in political and economic significance; equally, we highlight the role sports mega-events play in the region's most powerful states' soft power strategies. For the purpose of this paper, we focus on South Korea's soft power strategy and how the hosting of major sporting events has become a central part of this.

The use of sports mega-events (SMEs) for a variety of foreign policy and domestic goals is a globally widespread practice. Generally, "mega-events" are understood as 'large-scale, cultural (including commercial and sporting) events which have a dramatic character, mass popular appeal and international significance' [4] (p. 1). Countries as diverse in their economic development, culture, size and ideology as India, Qatar, the UK, Australia, China, Japan, Brazil and Russia have all hosted or will host major one-off sporting events motivated by a range of reasons, but all are seeking a number of different returns on their investment. Countries from every continent in the world (apart from Antarctica) and across a wide range of regime types (for example, democratic, illiberal, autocratic) have or will host an SME. There is a wide and growing literature on the so-called "legacies" that are thought to accrue from SMEs [5-7], and debates rage on whether such legacies can actually be "leveraged" through strategies developed prior to the event [8,9]. In general, the "legacies" that SMEs are said to bring range from economic benefits, a boost to tourism, international prestige, a feel-good factor among the home nation and urban regeneration $[5,10]$. One legacy thought the most sought after-apart from economic growth-is that of an increase in international prestige and "soft power" [11]. East Asia can be understood as a sports mega-event powerhouse with China, Japan and South Korea winning some 129 medals between them and ranking third, sixth and eighth in the medal table at the 2016 Summer Olympics [12]. The region also won the right to host three Olympic Games in a row: PyeongChang (2018, winter), Tokyo (2020(1), summer) and Beijing (2022, winter), after already hosting the FIFA World Cup (2002) and the summer Olympics (2008). China, Japan and South Korea belong to the group of nations that use a two-pronged sporting approach to soft power acquisition: they invest heavily in elite sporting prowess and in hosting expensive and expansive sports events.

The paper unfolds as follows: first, we introduce a literature review focusing on works on East Asia and soft power and the use of sport by East Asian nations to generate soft power. We then turn to the limited literature devoted to South Korea's quest for soft power through its culture and sport. The subsequent section introduces the methodology section which discusses an ideal type of states' "soft power strategies" developed by the authors in previous work [13]. This is used to develop and inform a tripartite approach to understanding how and why states use sport for "domestic", "regional" and "international" soft power gains. This effectively acts as an organising principle for the analysis of the case study of South Korea. Subsequent sections analyse the following sports mega-events hosted by South Korea: the 1988 (Seoul Olympics), co-hosting the 2002 FIFA World Cup with Japan and the more recent hosting of the 2018 Winter Olympics in PyeongChang. The significance of this piece lies in its application of the tripartite approach to understanding state rationales for hosting sports mega-events and in providing new empirical data to shed light on South Korea's use of SMEs, especially in 2002 and 2018, for domestic, regional and international purposes.

\section{Literature Review}

\subsection{Soft Power and Sport in East Asia}

Nations within a regional setting seek to improve their power positions within that region. China and Japan are two key regional states in East Asia and compete by the means of soft power: 'with their embrace of regionalism, each has concentrated soft power on East Asian neighbours by competitively proposing regional visions that would best position 
it in the regional leadership stakes' [14] (p. 77). However, with the rise of South Korea and its soft power resource, "Hallyu" (or "Korean Wave"), it complicates the regional competition. Lee suggests that the key sources of soft power in East Asia are economic (superpower) for Japan, an economic miracle and Hallyu for South Korea and military power, economic competitiveness and cultural heritage for China [15]. Additionally, China, Korea and Japan use soft power 'not only to supplement the country's hard power resources but also to achieve different national objectives' [15] (p. 12). South Korea's soft power resource, Hallyu (i.e., K-pop, K-Drama, films and more) was well leveraged during the 2002 FIFA World Cup that the country co-hosted with Japan, where Hallyu is currently considered mainstream regionally and internationally, signalling its strengths as a new regional contender and raising the nation's global positioning [16]. China had its "coming out party" hosting the 2008 Beijing Olympics and was more recently noted for its sport policy in line with its global economic, political and even cultural ambitions as a contender to a new world order [17]. Japan has celebrated the soft power scheme longest in the region since the nation had a "head-start" through its imperialism and the country's quick recovery from the Second World War and its modernization and innovations in technology, therefore being able to host the 1964 Summer Olympics [18]. Recently, in the search of a third national transformation as claimed by Nye [19], it is believed that Japan's hosting of the 2020(1) Tokyo Olympics can go some way towards "normalizing" Japan with their frequent attempts of attaining an offensive military against Article 9 of their constitution [16]. Increasingly, East Asian nations are turning to sports and sports mega-events to bolster their soft power. Hosting "first-order" events [20] (Black, 2008), such as the Summer Olympics, can transform nations into becoming part of the global community. According to Collins, 'hosting the Olympic Games serves as an allegory of the "universalization of universalism" in that the East Asian Olympics display the inevitable unfolding of the universal aspirations of the Olympic Movement' [21] (p. 163). Yu and Liu [22] (p. 2290) correctly suggest that the Summer Olympic Games hosted by China (2008), South Korea (1988) and Japan (1964) 'promoted their socio-economic development with great local, regional, and global implications' (authors' emphasis).

Although it is clear that the top three nations of East Asia (China, Korea and Japan) similarly promote their developments and soft power resources through sports megaevents with local, regional and international ambitions, we need to consider the extent to which each nation accepts the other's soft power. Due to their relations throughout history, South Korea and China both have some animosity towards Japan. In connection to the latter, Mangan et al. claim that 'there is a history of bitter rivalry between these countries, not least due to Japan's occupation of Korea and the Second Sino-Japanese War, the largest Asian war in the twentieth century' [23] (p. 108), which led to a common characteristic of Korean and Chinese nationalism: anti-Japanese antipathy [23] (p. 108). Thus, the regional competition in East Asia would appear never-ending as states vie to further their national interests; further, the use of SMEs to bolster their domestic, regional and soft power resources seems a rational course of action.

\subsection{Understanding 'Soft Power'}

It is fair to say that the concept of "soft power", coined by Joseph Nye at the end of the Cold War in 1990, has spawned a cottage industry of academic work in its own right. In an attempt to navigate through the vast literature on this topic, the following proposes to offer a concise summary of the extant literature before focusing on scholarship pertinent to the East Asia region. We narrow the focus still further by drawing on work that has explicitly used sport and soft power as its central focus.

In the intervening years since 1990, much ink has been spilt trying to work out precisely what "soft power" is, whether it can be generated and what impact it has on state diplomacy. In contrast to "hard power" (military intervention; economic sanctions, etc.), Nye suggests that states seek to indirectly adapt the political agenda in such a way that shapes the preferences of others through, for instance, emulating one's 'intangible assets': 
attractive culture, innovative ideologies, and/or credible and commendable institutions, values and policies [3]. Further, a state's soft power relates to its 'ability to achieve goals through attraction rather than coercion' [24] (p. 98), linking this concept to the notion of a 'politics of attraction' [25]. Such attraction, then, converts into power outcomes when those on the receiving end of the soft power strategy look to the state producing it for affirmation, guidance and leadership, or seek to imitate their domestic and/or international achievements [25] (see [9,13] for a thorough review of soft power).

Sports studies were late in drawing on the concept of "soft power" to explain how sports mega-events can be used as part of a state's public diplomacy armoury (see [26-28]. None of the earlier commentators in sports studies offered any mechanisms or ideal types by which "soft power" could be understood. The popularity of the concept among academics, politicians, think tanks and the media still offers but a broad-brush depiction of the rationale behind hosting SMEs. Increasingly, it appears self-explanatory that any state should seek to host a SME to grow their soft power. However, this tends to overlay the range of different reasons why states invest in SMEs. For example, the growing literature developing around "sport diplomacy", see [29,30], highlights the "ice-breaker" role sport can play in easing previously strained international relations, exemplified by several highprofile cases of the so-called "ping-pong diplomacy" between China and the USA during 1971 [31] and an attempt to repeat its success through "baseball diplomacy" between the USA and Cuba [32]. Such examples point to the formal, traditional and high-level, state-led sports diplomacy, but do not capture the newer, more networked version of unconventional sports diplomacy by a wide variety of actors [33]. Equally, as Kramareva and Grix suggest, there is a clear need to distinguish between 'levels' of diplomacy, that is, domestic, regional and international [34].

The growing popularity of the soft power concept is demonstrated most evidently through the increasing number of academics, politicians, governmental authorities, private institutions, agencies and journalists that have attempted to apply, adapt and/or measure soft power in their discussions of state-led policies. The former British Prime Minister, Theresa May, recently stated that "We [the United Kingdom] have the greatest soft power in the world-we sit in exactly the right time zone for global trade and our language is the language of the world." [35]. In addition, private agencies have begun producing annual soft power rankings of states. Portland Communication is one of the most widely cited annual rankings and has developed the yearly "Soft Power 30," which attempts to measure the soft power properties and subsequent public opinion of states, selecting the top thirty countries based on their diplomatic networks, cultural impact, governmental ideologies, level of education, digital infrastructure and economic capacity [36]. According to the most recent rankings of East Asia, Japan is the highest ranked state (9th in 2019) with South Korea at the 19th spot and China at the 27th [36].

To fully understand South Korea's use of a soft power strategy, it is necessary to discuss briefly the difference between soft power that derives organically from civil society, culture and non-governmental organisations on the one hand and state-led soft power strategies on the other. South Korea, along with Russia and China, clearly pursue a predominantly state-led soft power strategy alongside the more informal cultural Hallyu described above. Watson [37] (p. 314) rightly suggests that South Korea's global brand ' . . is the latest in a long line of instrumental official state-led narratives on rebranding a specific South Korean national identity as the legitimate Korea'. Thus, a state-led soft power strategy becomes more about shaping a country's image and national identity, rather than attempting to use the "politics of attraction" to persuade others to do what you want. Such a strategy, explains Wilson [38] (p. 287), using the example of Russia and China, seeks to 'construct a national identity that maintains the current regime and contests Western dominance in the prevailing international order'. This is not to suggest that South Korea is similar to Russia or China in their governance or soft power aims; the point here is to underscore the different types of soft power strategy that can be employed. 
The next section introduces the methodology used in this study and the subsequent sections seek to focus on and outline South Korea's political use of SMEs in the 30 years from 1988 through to 2018.

\section{Methodology}

In this study we seek to find answers to the key research question: 'what is South Korea's rationale for hosting sports mega-events?'. The organising principle behind this article is derived from an adapted version of the authors' ideal type of a state's "soft power package" published in 2016 (see Figure 1 below). This ideal type is clearly externally focused and fails to take into account the domestic, regional and international aspects of soft power acquisition. In previous work the authors [17] found that the soft power emphasis of a particular state depends on its own stage of development and rationale, for it may be international, regional or domestic. Some states, for example, China, may attempt to hit all three of these target audiences. While regional and international may be considered "external" soft power, they differ for the actors that pursue them. A regional power, such as Brazil, South Korea or Japan, will seek to uphold its regional status in addition to attempting to move towards global status. Equally, as we discuss below, the external showcasing of a sports mega-event may serve to bolster domestic politics and national identity building, as was the case in Russia [34].

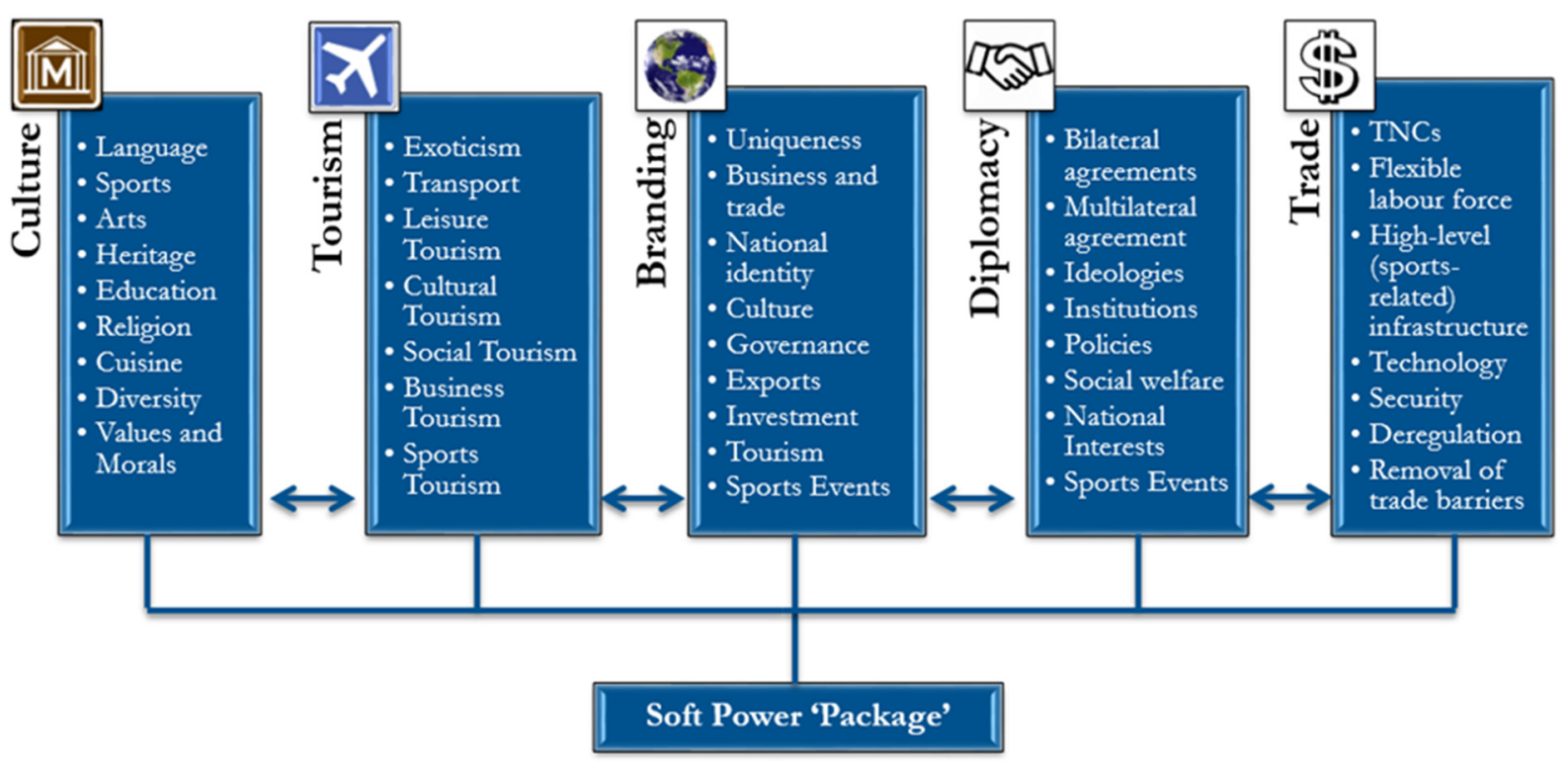

Figure 1. The Soft Power Package. Source: Grix and Brannagan in [13], 2016.

Thus, in this study we seek to rectify the lack of a tripartite analysis in the original ideal type by applying the domestic, regional and international lenses to the South Korean case as a focus across the state's three key sports events in 1988, 2002 and 2018. Thus, these three SMEs act as the micro case studies in this paper. This study then adds a regional dimension to Putnam's 'two-level game' (domestic and international politics) [39] to capture South Korea's soft power strategy using sports mega-events.

The original soft power package is below and aids research in pointing to the key factors involved in soft power acquisition. This generic ideal type informs our "tripartite" analysis of South Korea's motives for hosting sports mega-events from 1988 to 2018.

Sources for this study range from secondary academic literature and an analysis of a range of media and government documents to 10 interviews and one focus group (three participants) with selected people with the ability to contribute relevant information connected to this research [40] (p. 277). In-depth, semi-structured interviews were conducted over the period from October to December 2019. Interviewees were approached using the 
snowball sampling technique, where 'researchers usually start with a small number of initial contacts (seeds), who fit the research criteria and are invited to become participants within the research' [41] (p. 3). These interviews were based on a protocol aimed at prompting interviewees to reflect on South Korea's rationale for hosting SMEs, the key actors involved in this, the outcomes and any lessons learnt. The average length of interviews ranged from 1 to just over $2 \mathrm{~h}$; all were taped, professionally transcribed and then sent back to the interviewee to be checked and agreed. The interviewees were selected from the following (numbers of participants in each group in brackets):

1. National Olympic Committee/National Football Association (representatives and members involved in organising the respective events) (2);

2. Government Personnel (involved in organising respective events) (7);

3. Sports Industry (1);

4. Academic Scholars (3 (focus group)).

The three focus group participants were selected from scholars from Yonsei University's Department of Public Administration. Three participants were chosen in this field due to accessibility and because the purpose of this discussion is not to come to a final consensus but to create an atmosphere for participants to freely express their opinions and thoughts in agreement or disagreement [42]. In addition, only one focus group was used to elicit general opinions on the topic instead of specifically segmenting the research to a certain age group, social status, or gender, which is misleading for the purpose of this research. The analysis of the transcripts was undertaken without the aid of any software but was discussed and developed by the two lead authors. As a guiding principle, the authors used Braun and Clarke's [43] well-cited step-by-step guide to thematic analysis, drawing out first broad themes and then working to narrow them to a few salient themes. The authors also had the tripartite approach, as previously introduced (domestic, regional and international), to help shape the thematic analysis.

The methodological approach adopted in the current work reflects a variant of a postpositivist position. Whilst maintaining a worldview closely aligned with interpretivism, the researchers posit an epistemological position that resides "on the border" of interpretivism and critical realism (termed "hard" interpretivism) and, as such, seeks to allow room for both actors' beliefs and structures in explanations of social phenomena [44,45].

\section{South Korea's Use of Sports Mega-Events for Domestic, Regional and International Soft Power}

East Asia has recently become a hot house of SME hosts. The region won the right to host three Olympic Games in a row: PyeongChang (2018, Winter), Tokyo (2020(1), Summer) and Beijing (2022, Winter), after already hosting the Summer Olympics (1988; Seoul), FIFA World Cup (2002; Japan and Korea) and the Summer Olympics (2008; Beijing). South Korea, one of the four so-called "tiger economies" in (South) East Asia, has turned to sports mega-events to keep pace with its key neighbours in the region, China and Japan.

In what follows, we seek to understand South Korea's rationale for hosting SMEs; while the empirical focus is on the 2002 FIFA World Cup and the 2018 Winter Olympics, we draw on the 1988 Seoul Olympics for insights to understand if, and how, the reasoning behind hosting changed over time.

\subsection{South Korea's Rationale behind Hosting the 1988 Seoul Olympics}

According to the IOC, awarding the 1988 Summer Olympics to South Korea 'provided the impetus for the country to embrace democracy' [46]; however, the process of South Korea's democratisation can be traced to a set of reforms, including the presidential electoral system [47]. There have been many events that led to the awarding and hosting of the Summer Games. South Korea was awarded the 1988 Games against Japan's Nagoya on 30 September, 1981 in West Germany [48], during a period when the country was led by Chun Doo-hwan, an autocrat, who was president from 1980 to 1988 [49] (p. 131). Tensions from the populace 'led to the Great June Uprising of 1987, when the people of 
South Korea won direct presidential elections through 19 consecutive days of mammoth demonstrations' [50] (p. xi); this can be understood as the actual driving force towards South Korea's democratisation. It is easy to assume that the rationale for South Korea to host the 1988 Games was to show the international community that they are a democracy or that they were using the Games to become one, as the IOC has claimed. However, an explanation of South Korea's rationale for hosting is better found by taking into account the country's domestic, regional and international ambitions at the time.

Domestically, South Korea had gone through many infrastructural changes, with former president Park Chung-hee initiating the industrialisation of South Korea and its economy. However, it is imperative to understand the number of major events that South Korea had endured up until the hosting of the 1988 Games. Korea was coming out of the mist of World War II amidst the end to Japanese colonialism in 1946, when it formed the Korean Olympic Committee (KOC) and formerly joined the IOC in 1947 [51] (p. 275) (Cho and Bairner, 2012: 275). From the 1960s onwards, Korea participated in a number of international sporting events cementing the nation's status as a 'strong sporting country' [51] (p. 275). In fact, many politicians believed it important to focus on elite sport development for national prestige and to pursue political objectives during military rule [52,53]. Indeed, Cha [54] (p. 148) purports that the South Korean government use of the 1988 Games to legitimise a military dictatorship was akin to the Chinese Communist Party's political use of the 2008 Beijing Olympics. Above all, the South Korean government needed to send a reassuring message to its citizens that the nation had recovered and had greatly developed after Japanese colonialism and the Korean War. The hosting of the 1988 Games was the best vehicle through which to emphasise 'nationalism-nationalism and national unity grounded in traditional Korean loyalty and patriotism' [52] (p. 3).

Regionally, South Korea's love-hate relationship with Japan is worth noting. The origin of Korea's enmity towards Japan comes from Japan's occupation of Korea [55] (p. 283). However, Manheim [55] (p. 283) claims that even though Korea had much animosity towards Japan, South Koreans still noticed the massive economic growth of post-war Japan and 'have adapted some Japanese development techniques to their own needs' - mainly planning to rival Japan as an economic power. The Seoul Olympic Sport Promotion Foundation [56] recalls that when Korea's sporting politicians visited Japan in 1979, Japanese politicians expressed to Park Sung-Kyu how hosting the Tokyo Olympics in 1964 contributed greatly to Japan's developing economy and raised the pride of Japanese citizens after the experience of the Second World War. Thus, this contributed to South Korea's decision to bid for the 1988 Games, when Mr. Yanagawa, a Japanese politician who was aware that Seoul was Nagoya's only competition to the bid, invited Park Sung-Kyu to Japan again in February 1981, and asked the Korean delegation to forfeit their preparation for the Olympic bid [56]. This was no different from Japan asking the Korean delegations to give up their nation's regional and domestic ambitions. According to Cha [57] (p. 1292), South Korea winning the bid against Japan's Nagoya was bittersweet, since Korea not only won over their rivals but created an opportunity to raise their status in the region and attain global recognition.

Furthermore, the awarding of the 1988 Games consequently became a stepping stone to another sporting event. After the IOC awarded South Korea the 1988 Olympics, the Asian Games Federation chose South Korea to host the 1986 Asian Games, which was important to South Korea's regional relations. As Ha [18] (pp. iii-iv) stated, both 'Games provided South Korea chances to display its achievements to a world audience and improve its diplomatic relations with communist countries. Yet, South Korea failed to create harmony or progress in its relations with North Korea'; they boycotted the 1988 Games with Cuba, Nicaragua and Ethiopia [46]. Although failing to do much with North Korea, South Korea was able to show its neighbouring countries that the nation had the ability and credibility to host both the 1986 Asian Games and the 1988 Olympics. It was a sign that South Korea was developing, and it wanted to show that to the much larger nations of China, Japan, and Russia. Joining the global community and being able to commercialise Seoul and 
South Korea to the world was an indirect message to its neighbouring countries, which likely fuelled the competition of hosting SMEs and many other international or regional sporting events.

Internationally, and specifically in international relations, South Korea wanted the ability to communicate and express their identity globally; something Cho and Bairner [51] (p. 281) claim the hosting of the 1988 Games allowed. In addition, Trunkos and Heere [58] (p. 8) suggest that South Korea provides a good example of using a sports mega-event to expand their state's capabilities in international relations. South Korea used the 1988 Seoul Olympics 'as a tool to improve their relationships with the (then) USSR and Eastern European nations, and were successfully able to prevent these nations from boycotting the Olympics in support of North Korea' [58] (p. 8).

The 1988 Olympics also allowed South Korea an ideal opportunity to introduce a new sport to the Olympic Summer Games and to the world: South Korea's traditional martial arts, Taekwondo. Moenig and Kim [59] (p. 1) claim that the globalization of Taekwondo started in the aftermath of the Korean War (1950-1953), as the result of the Korean diaspora, when a number of Korean martial arts instructors emigrated to the United States.' Credit was also given to American military personnel, who were responsible for the early spread of Taekwondo, as they founded 'some of the first Korean martial arts clubs in the United Stated and other countries' [59] (p. 1). South Korea thus created what one could term a "benefactory soft power resource," a resource that has a long-term legacy effect that ultimately helps a nation. All Taekwondo needed was a global stage after the Park Chung-hee regime declared it as South Korea's "national sport", and it was proclaimed as the nation's first successful international cultural export [59] (p. 1). That stage was the 1988 Summer Olympics in Seoul. Porteux and Choi [60] (p. 70) point out how South Korea introduced Taekwondo as a demonstration sport in Seoul (1988) and that it then became an official event from the Sydney 2000 Olympics onwards. This is a prime example of a state-led soft power strategy and 'was strategically used and sponsored by the South Korean government for soft power and more profoundly for increasing the profile of the nation.' (ibid.). Kang and Houlihan [61] (p. 31) concur that South Korea's main strategies were hosting international SMEs and promoting Taekwondo with the purpose of attaining and promoting positive images of the nation abroad.

Understanding South Korea's domestic, regional and international rationale behind hosting the 1988 Summer Olympic Games not only shows the political side of hosting firstorder, sport mega-events, but also the impact the event had on the state's modernization and emergence on the global stage. The next section discusses South Korea's rationale behind hosting the 2002 FIFA World Cup.

\subsection{South Korea's Rationale behind Co-Hosting the 2002 FIFA World Cup}

A similar strategy to the 1988 Olympics was evident again in South Korea's joint hosting of the 2002 World Cup. The nation's motive for hosting was both to ameliorate relations with Japan, showcase their nation's technological advancements and to broaden the starting point of Hallyu, a concept already well accepted within East Asia by the 1990s [62].

\section{FIFA World Cup}

FIFA announced in 1996 that the World Cup would be hosted by two co-hosts, South Korea and Japan. At a conference in Zurichm Alan Rothenberg, the then president of the United States football federation, referred to the relations between South Korea and Japan, statin: 'If it works, it will be very important for the World Cup to be co-hosted by two countries without a great history of friendship. This proves that sport, and particularly soccer, can make a difference' [63]. Despite the South Korea-Japanese enmity, the 'protracted bidding process ... remained heralded by sporting bodies world-wide as one very positive step towards the establishment of a truly positive relationship between the host nations' [64] (p. 484). McLauchlan continues by comparing this event to US President Nixon's so-called "Ping-pong diplomacy" with China that 'aimed at bridging the 
Cold War gulf between the two nations by allowing China to take part in the World Table Tennis Championships in Nagoya in 1971' [64] (p. 484). For others, it was assumed that Korea's bid for the 2002 World Cup was to utilise it as a 'catalyst for peace' on the Korean Peninsula [65] (p. 118). The following analyses the domestic, regional and international rational of hosting the 2002 FIFA World Cup at the time.

The period from 1980 to 1997 was the era of an emerging "modern" South Korea when economic celebrations ended with the outbreak of the 1997 Asian financial crisis [66] (p. 978). This was a year after FIFA announced that South Korea were to co-host the 2002 World Cup with Japan. Kim Young-sam, the South Korean president from 19931998, used the 2002 World Cup to boost his state's citizens' confidence and to create a nationally collective society. He did this by jogging in a '2002 World Cup T-shirt and cap' [67]. The financial crisis led to Kim Young-sam losing his political legitimacy and being 'accused of mismanaging the economy during the Asian financial crisis that toppled some of the country's debt-ridden conglomerates and forced the government to accept a $\$ 58$ bn bailout from the IMF' [68]. Due to the bailout, civic groups began calling on Koreans to make sacrifices for the good of the country, where millions of households collectively sold their possession of gold to help contribute to resolving the IMF crisis-even the likes of the then president, Kim Dae-jung, joined in the act of donating gold [69] (pp. 125-126). After resolving the financial crisis, it not only displayed the strength of South Korea's collective society but also displayed to the global audience that South Korea is a 'can do nation' capable of dealing with difficult situations in [16] (p. 73). One interviewee for this study (Yook Dong-han, Korean Presidential Secretariat; 2018 Pyeongchang Winter Olympic Executive Committee Member November, 2019) suggested that:

Even though hosting the World Cup was right after the Asian financial crisis in 1997, where the economy was getting worse, national morale was down, unemployment was on the rise, it was still the right time for South Korea to host the World Cup in 2002 for recovering from the financial crisis quickly. The citizens believed, with the confidence attained from hosting the 1988 Seoul Olympics, they should be able to host the 2002 World Cup.

With the strategy of strengthening South Korean's confidence, Kim Young-sam was successful in solidifying South Korea's already collective society, although overcoming the financial crisis can be credited to the Korean citizens' collective actions. The collective action of overcoming the financial crisis was bolstered by the feel-good factor and national pride derived from hosting the 1988 Seoul Olympics, which was a key domestic rationale behind hosting the 2002 FIFA World Cup [70].

Regionally, South Korea was well known for its pop culture in the early 2000s. Hallyu or the "Korean Wave" are both umbrella terms for Korean cultural trends. These trends consisted of 'an increasing amount of Korean popular cultural content-including television dramas, movies, pop songs, and their associated celebrities-and had gained immense popularity in China, Taiwan, Hong Kong, and other East and Southeast Asian countries' [71] (p. 25). Of these contents, Korean dramas or films, known as "K-dramas" or "K-films" and Korean pop music, "K-pop," are currently very popular regionally and globally. For example, Psy's "Gangnam Style" in 2012 had an historic 2 billion views on Youtube [72], and South Korea's BTS (Bangtan Sonyeondan) is currently on the top of the Billboard Top 100 rank with their new song titled "Butter" [73]. Before its global reach and after its rise in the region, an interviewee recalls (Im Chae-min, former Minister of Health and Welfare/Korea/Japan World Cup Director of Media Support for the World Cup Organizing Committee, October 2019):

Hosting the 2002 World Cup contributed to the rise and emergence of Korea's Hallyu. In 2001 December 1, in Busan, Korea held the World Cup Group Stage Draw where it would present which nations would play another in slots. While proceeding with this event there were many performances and celebrities. The event was planned with entertainment management companies and professionals in the field of cultural policy. 
It is well known that SMEs are used as a vehicle to showcase a nation. South Korea used the 2002 World Cup as a stage to leverage several Hallyu resources and as a vehicle to maintain regional Hallyu consumers, which resulted in a sustainable rise in Hallyu consumers in East Asia. Despite the difficult relationship with its neighbour, K-pop and dramas are still mainstream in Japan [74].

Another common regional factor behind South Korea's hosting of the 2002 World Cup was their competition with Japan. One strong claim voiced was that if the World Cup were to be held in Asia, South Korea would be the better decision given that they had qualified for the World Cup four times (currently nine times since 1986) in a row before 2002, which was the best record of any East Asian nation (Lee Y. S., former Vice President of the Korean Football Association/Professor at Sejong University Department of Education October, 2019). For others, South Korea wanted to prove their capabilities to Japan and other East Asian nations and raise their competitiveness in the region. Although it may not be the main motive, the frequent references to South Korea's rivalry with Japan indicate the need for the former to show it is in the position to successfully host major sporting events in the East Asian region.

South Korea made its international sport-event hosting debut in 1988 and needed something more than just putting themselves on the map or a "coming out party" [75] (p. 65). With the Asian financial crisis and a communist North Korea, there were existing negative images of South Korea, and the country had the ambition to show that the nation had developed and could be a credible global player. Co-hosting the 2002 FIFA World Cup was very fortunate for South Korea, for it was their international game changer. The FIFA World Cup offered the perfect global stage to showcase South Korea's technological advancements [76] and make Hallyu more than just a regional mainstream phenomenon [77]. This was well stated by an interviewee (Ma Young-sam, Public Diplomacy Ambassador of the Ministry of Foreign Affairs and Trade; Korean Ambassador to Denmark and Israel, November, 2019) when he suggested:

The World Cup hosting in itself was a huge resource for Korea's soft power. After hosting the games, many people started to become interested in Korean culture, arts, and what Korea is well known for now, Korean pop-culture. The 2002 World Cup was another chance for the world to see Korea again as much more credible and attractive. Soft power is about being able to attract other people around the world to the nation's cultural assets. The World Cup was the perfect showcasing of Korea and its soft power assets.

South Korea used the 2002 World Cup momentum well by hosting the nation's largest mobile communication exhibition, 'Expo Comm Korea 2002', in order to showcase the nation's technological advancements Here, the 'latest Information Technology (IT)-related products and services gathered' [78], where Samsung Electronics, LG Electronics, SK Telecom, KTF and more were able to show off their latest technology and internet service speeds [78], indicating the nation's development.

South Korea's Hallyu was already thriving in Asia, and South Korea had the ambition to naturally showcase this to inbound tourists from around the world during the World Cup. Thus, it was understood as something that could attract touristsand South Korea's tourism industry did undergo '... unprecedented growth and faced multiple changes since 2000, thanks to the recent emergence and growing popularity and influence of the Hallyu' [79] (p. 524). Horne [80] (p. 1218) also acknowledges that 'the use of popular culture, including sport, as a vehicle for "soft power" influence between nation states has been increasingly recognized.' This was exactly what South Korea had in mind when co-hosting the 2002 World Cup; the nation was trying to give the global audience a sense of "Korean-ness."

South Korea had the ambition to re-emerge as a new contender of regional power and global reach. In short, domestically, South Korea constructed a resilient collective society; regionally, the state took advantage of the popularity of Hallyu to maintain and grow its consumers within Asia. Internationally, South Korea planned to showcase Korean technology advancements and capabilities while also finding ways to disperse Hallyu 
globally-with both considered mainstream now. Hosting an SME such as the FIFA World Cup was more than important for South Korea's domestic, regional and international development, even though it was shared with their rival, Japan.

\subsection{South Korea's Rationale behind Hosting the PyeongChang Winter Games, 2018}

South Korea's most recent SME was hosting their first Winter Olympics in Pyeongchang in 2018. After being denied twice consecutively until July 2011, the IOC finally awarded South Korea the right to host [81] (p. 2365). According to Campbell [82], South Korea was leveraging Pyeongchang, 2018, to promote peace on the Korean peninsula-for example, by suggesting that it was South Korean president Moon Jae-in's last attempt to maintain and bolster his political legitimacy dealing with North Korea. Although the latter is one of the rationales behind hosting the event, it is possible sport diplomacy was an overstated role pertaining to the outcome of North and South Korea relations after Pyeongchang 2018. As we analyse below, there are a number of domestic, regional and international reasons for hosting the 2018 Winter Games.

Domestically, South Korea's bid for the 2018 Winter Olympics was seen as an attempt to boost infrastructural development within the Gangwon province and attract tourism to the area where the Asian Winter Games in 1999 in Yongpyong had taken place [83] (p. 302). The estimated cost of the capital investment by South Korea is about USD 13 billion [84]. This type of investment also aids in raising inbound tourist expenditures. According to Wood and Meng [85] (p. 17), 'the spending of tourists attracted by the Winter Olympic Games is estimated to generate 2 trillion won of output, 324 billion won of income, 744 billion won of added value and create 19,097 jobs. Compared with the operational cost of 1.7 trillion won, the effect of increased tourism demand alone can generate net economic benefits, even without including revenue from broadcasting.' On the other hand, South Korea was not only reviving the nation's economy but more specifically attempting to revive the Gangwon province's depressed economic situation, with the belief that hosting the Winter Olympics would 'develop the province into an Asian winter sports and logistics hub, and thus encourage its economic growth' [] (p. 7). In addition to infrastructure construction, transportation developments were 'expected to facilitate geographically dispersed interregional links in the Gangwon province' [86] (p. 7). As explained by a Gangwon official, who was deeply involved in the PyeongChang Olympics (Jeong-Kwon Byeon, Gangwon Provincial Manager for the PyeongChang Winter Games, May, 2019):

Gangwon Province is a very remote area, so Gangwon Province has never held a big event like the Olympics. The reason why Gangwon-do tried to host the Olympics three times is because the Olympics can be a catalyst for development in the area. Gangwon Province was hoping for the influx of external capital such as government funds through hosting the PyeongChang Olympics.

The Gangwon province had a positive outlook on their chances of hosting the event, with one report, referring to the bid for the 2010 event, claiming:

The possibility of winning the winter event can be analyzed based on the following two factors. First, based on the principle of circulating to each continent, the 21st (2010) event should be given to the Asian continent, since it has already been held on the other continents: the 18th (1998) Asia (Japan), the 19th (2002) North America (the US) and the 20th (2006) Europe (Italy). Second, Korea is the most promising country to host the winter event given its experience in hosting global mega sporting events and thanks to its weather conditions [81].

However, with all the planning and certainty, Pyeongchang lost to Vancouver by a mere three votes in the final round [81]. With this, Kang and Kim [87] note that South Korea was trying to raise local residents' pride in the province, since showing consistency and resilience paid off and helped officials promote Pyeongchang to keep their promise to Gangwon residents [81]. It took a third bid for Pyeongchang to be awarded the rights to host the Winter Olympics, which is usually the case with many bidders [9]. 
Regionally, South Korea was not only trying to revive the Gangwon province but trying to attract tourists from within the region and internationally. The nation hosted three major SMEs in two decades-the 1988 Seoul Olympics, 2002 FIFA World Cup and 2018 Pyeongchang Winter Olympics [81], which are ideal platforms for showcasing South Korea, as well as attracting and increasing inbound tourism. However, as claimed before, South Korea's Hallyu (especially K-pop, K-drama and films) was already famous in the East Asian region early on and did well in maintaining the number of Hallyu consumers in the region [81]. It seems that the two cultural resources, an SME and Hallyu, work well in leveraging each other, therefore creating an even more favourable outcome regionally and internationally [88]. This was mentioned by one of this study's interviewees (Seong-Il Baek, Vice President of the Games Operations of the PyeongChang Winter Games, May, 2019):

I'm the only one person who has worked at both 1988 Seoul Summer Olympics and 2018 PyeongChang 2018 Winter Olympics in KOC. When I went to Sao Paulo for the Seoul Olympics in 1986, no one knew about Korea at that time, but everyone knew about the Seoul Olympics, even though it was two years before the event. Hosting the Seoul Olympics Games was a great moment to let the world know about Korea. By hosting the PyeongChang Games, Korea has become one of the few countries in the world with experience in hosting both the Summer and Winter Olympics, I think this has been an opportunity to further enhance South Korea's international reputation.

A key, reoccurring regional rationale for hosting SMEs is the rivalry between South Korea and Japan. In the East Asian region, Japan has hosted the Winter Olympics twice, first in Sapporo in 1972 and then Nagano in 1998, although it would have been a third Winter Olympics, if Japan were able to host in 1940; it was cancelled due to the rising tensions of World War II [89]. Furthermore, Japan has hosted the Asian Winter Games four times (1986, 1990, 2003 and 2017), which clearly shows Japan's capability for hosting winter sports events. Even China has hosted the Asian Winter Games more often than South Korea in 1996 and 2007 [90] (p. 1048), whereas South Korea has only hosted it once in 1999 in the Gangwon province. Therefore, if South Korea wanted to be a contender as a winter sports and logistics hub in Asia, there was no other large-scale winter sporting event that could "prove a point" other than the Winter Olympics.

Internationally, South Korea needed to find a way to put out a statement that the country is not only a sports powerhouse but also a nation capable of global standards in hosting SMEs. In order to do this, South Korea determined to join what could be called the "Four Grand Slam SME Club." When South Korea was awarded the 2018 Winter Games, this meant that South Korea became only the fifth nation globally, joining France, Germany, Italy and Japan, to have hosted the Summer Olympics (1988), the Winter Olympics (2018), the FIFA World Cup (2002) and the International Association of Athletics Federation (IAAF) World Championship (2007) [91]. Additionally, with Pyeongchang being the finishing piece to the puzzle, it became the eighth nation to hold both the Summer and Winter Olympics (ibid.). While joining the global club of SME hosts afforded South Korea the international coverage and prestige it desires, other international goals lay behind the hosting of the 2018 Winter Olympics.

South Korea presented the 2018 Pyeongchang Winter Olympics as the Olympics of culture, environment, peace, economy and information and communications technologies (ICT) [92]. Focusing on the "ICT Olympics" aspect, South Korea planned on showcasing five advanced ICT-based services to enrich the Winter Olympics experience, which were: the world's first use of 5G communications networks, the internet of things (IoT), ultrahigh definition (UHD), virtual reality (VR) and artificial intelligence (AI) [92]. South Korea wanted to show that the nation was at the forefront in technological advancements and wanted to maintain their products in the mainstream. It should be noted that Korean technology products are also a type of resource within Hallyu [88]. By hosting Pyeongchang 2018, South Korea believed that it could raise the status of Korean tech products [87] and enhance its global pop culture status [93]. 
Ultimately, South Korea wanted to bring the Winter Olympics home because of the government's strong belief that it would bring North Korea back to the negotiating tableespecially with the US [94] in a form of sports diplomacy [34]. There have been a number of political boycotts involving SMEs, not least North Korea not attending the Seoul 1988 Olympics. In contrast, South and North Korea agreed to march under one flag at the opening ceremony and also had a unified Korean women's ice hockey team during the Winter Olympic Games in 2018. The opening ceremony of the event was even termed "Peace in Motion" [94]. This is evidence-in the short-term—that SMEs can go some way to support Pierre Coubertin's original Olympian ideal of sport promoting peace [95]. In this regard, a member who was deeply involved in the Olympic Games held in Korea (Dong-Kwang Shin, Director Budget and Marketing of the Korean Sport and Olympic Committee, May, 2019) suggested that:

The PyeongChang Olympics Games was a good example of world peace through sport. The diplomatic channel of communication between both Koreas, which started through the participation of North Korea in the PyeongChang Games, restored again and that became the starting point of the inter-Korean summit. It was a great moment between the South and North Korea that the two countries with an armistice have a summit meeting, which discussed a declaration of the end of civil war and a solution to the denuclearization of the Korean peninsula. South and North Korea are hoping to launch a joint bid for co-hosting the 2032 Summer Olympics. The PyeongChang Olympics was a pivotal opportunity to improve inter-Korean relations and the IOC's role was important from the central government's perspective.

Another interviewee, who was one of the members of the high-level talks with North Korea for the PyeongChang Olympics attended by a total of five South Korean delegates, (Ki-hong Kim, Secretary General and Executive Vice President the POCOG and Deputy Minister, May 2019) stated that:

Through the PyeongChang Olympics, the inter-Korean summit was held three times, and the US-North Korea summit was a success. It was considered a historical moment. In addition, the President of the IOC, Thomas Bach prepared a meeting for the co-host of the 2032 Olympics in Lausanne on 15 February. This can be seen as contributing to peace around world as well as in Northeast Asia, except the relationship between the two Koreas ... I think the peaceful mode between the two Koreas at the PyeongChang Olympics served as an opportunity to show the international community the easing of tensions originally caused by the security issues on the Korean peninsular.

The most recent South Korean SME afforded a number of opportunities for the state. Domestically, the Gangwon Province has benefitted greatly from infrastructural investments due to hosting the PyeongChang Olympics. Regionally, South Korea has increased in importance by becoming one of only a handful of states to have successfully held both the summer and winter Olympics (and the IAAF World Championships). Internationally, the PyeongChang Olympics will be remembered, in part, for its role in easing tensions between the two Koreas.

\section{Conclusions}

This study has offered both a new tripartite analysis (Domestic/Regional/ International) and new empirical data to aid the study of states' motives for hosting sports mega-events. In particular, we focused on a case study of the use of sports megaevents by South Korea, introducing and analysing the case studies of the Seoul Olympics (1988), the co-hosting of the FIFA World Cup (2002) and the hosting of the 2018 Winter Olympics. By dissecting the analysis of states' motives for hosting SMEs into three levels, we can move scholarship beyond the simplistic platitudes of "sports mega-events equals soft power", which overlooks a much more complex set of economic, political and cultural factors that influence each host and their motivations. Clearly, South Korea's role as a key regional actor in East Asia is important to any understanding of why it would want to 
host global sporting events; however, as we have shown, there are an equal number of reasons to host at both the domestic and international levels. Japan's recent hosting of the beleaguered Tokyo 2020(1) Olympics are another example of a key East Asian actor seeking to strengthen its position in the region, showcase its nation internationally and use the event to change attitudes and mindsets domestically. We suggest that South Korea pursues a predominantly state-led soft power strategy and as such, much of the focus is on shaping the country's image regionally and internationally and its national identity, rather than explicitly attempting to use the "politics of attraction" to persuade others to play into South Korea's hands. However, the "politics of attraction" does appear to work when the soft power resource is organic, for example, with the increasingly influential cultural sector, including K-pop, film (cf. Parasite) and international TV hits (cf. The Squid Game). The success of the PyeongChang Olympics did bring about a major thaw in inter-Korea relations, albeit only in the short-term. If the Games had not taken place, the positive (sports) diplomacy generated by the event-and which led to inter-Korean and US-North Korea summits-would not have happened. For this reason, it is highly likely that South Korea will continue to seek hosting rights to SMEs to fulfil its domestic, regional and international ambitions.

While this analysis along domestic, regional and international levels may be rudimentary, it is the first attempt to categorise why and how states strategise regarding the role of sport in soft power acquisition. This three-pronged approach can be extended to any SME host so long as it is embedded within the economic, social and (geo-)political context of the case being studied.

Author Contributions: Conceptualization, J.G.; Data curation and majority of interviews, J.B.J.; Formal analysis, H.K.; Methodology, J.G.; Project administration, J.B.J.; Resources, H.K.; Writingoriginal draft, J.G.; Writing - review \& editing, J.B.J. All authors have read and agreed to the published version of the manuscript.

Funding: This research received no external funding.

Institutional Review Board Statement: The study was conducted according to the guidelines of the ethics committee at Manchester Metropolitan University; it was approved by the same committee, Ethics reference number 1125, 9 April 2019.

Informed Consent Statement: Informed consent was obtained from all subjects involved in the study.

Data Availability Statement: Not applicable.

Conflicts of Interest: The authors declare no conflict of interest.

\section{References}

1. Ikenberry, G.J. The End of Liberal International Order? Int. Aff. 2018, 94, 7-23. [CrossRef]

2. Muggah, R. The Global Liberal Order Is in Trouble-Can It Be Salvaged, or Will It Be Replaced? weforum.org. Available online: https:/ / www.weforum.org/agenda/2018/04/can-the-global-liberal-order-be-salvaged/ (accessed on 3 June 2021).

3. Nye, S.J. Soft Power. Foreign Policy 1990, 80, 153-171. [CrossRef]

4. Roche, M. Mega-Events and Urban Policy. Ann. Tour. Res. 1994, 21, 1-19. [CrossRef]

5. Preuss, H. The Conceptualisation and Measurement of Mega Sport Event Legacies. J. Sport Tour. 2007, 12, 207-228. [CrossRef]

6. Girginov, V. Governance of the London 2012 Olympic Games Legacy. Int. Rev. Sport Sociol. 2012, 47, 543-558. [CrossRef]

7. Leopkey, B.; Milena, M.P. Olympic Games Legacy: From General Benefits to Sustainable Long-Term Legacy. Int. J. Hist. Sport 2012, 29, 924-943. [CrossRef]

8. Chalip, L. Towards Social Leverage of Sport Events. J. Sport Tour 2006, 11, 109-127. [CrossRef]

9. Bason, T.; Grix, J. Every Loser Wins: Leveraging 'Unsuccessful' Olympic Bids for Positive Benefits. Eur. Sport Manag. Q. 2020, 1-21. [CrossRef]

10. Grix, J.; Paul, M.B.; Wood, H.; Wynne, C. State Strategies for Leveraging Sports Mega-Events: Unpacking the Concept of 'Legacy'. Int. J. Sport Policy 2017, 9, 203-218. [CrossRef]

11. Haut, J.; Grix, J.; Brannagan, M.P.; van Hilvoorde, I. International Prestige through 'Sporting Success': An Evaluation of the Evidence. Eur. J. Sport Soc. 2017, 14, 311-326. [CrossRef]

12. Lee, J.W.; Tan, T.C. The Rise of Sport in the Asia-Pacific Region and a Social Scientific Journey through Asian-Pacific Sport. Sport Soc. 2019, 22, 1319-1325. [CrossRef] 
13. Grix, J.; Brannagan, M.P. Of Mechanisms and Myths: Conceptualising States 'Soft Power' Strategies through Sports Mega-Events. Dipl. Statecr. 2016, 27, 251-272. [CrossRef]

14. Sohn, Y. Attracting Neighbors: Soft Power Competition in East Asia. Korean J. Policy Stud. 2011, 26, 77-96.

15. Lee, S.W. The Theory and Reality of Soft Power: Practical Approaches in East Asia. In Public Diplomacy and Soft Power in East Asia, 1st ed.; Lee, S., Mellisen, J., Eds.; Palgrave Macmillan: New York, NY, USA, 2011; pp. 11-32.

16. Jeong, J. How Nations Use Sport Mega-Events to Leverage Soft Power: A New Rise in East Asia. Ph.D. Thesis, Manchester Metropolitan University, Manchester, UK, 2021.

17. Grix, J.; Brannagan, M.P.; Lee, D. Entering the Global Arena: Emerging States and Sports Mega-Events, 1st ed.; Palgrave Macmillan: London, UK, 2019; p. xiii-117.

18. Tagsold, C. Modernity, Space and National Representation at the Tokyo Olympics 1964. Urban History 2010, 37, 289-300. [CrossRef]

19. Nye, S.J., Jr. Soft Power: The Means to Success in World Politics; Public Affairs: New York, NY, USA, 2004.

20. Black, D. The Symbolic Politics of Sport Mega-Events: 2010 in Comparative Perspective. Politikon 2007, 34, 261-276. [CrossRef]

21. Collins, S. Asian Soft-Power: Globalization and Regionalism in the East Asia Olympic Games. In Proceedings: International Symposium for Olympic Research; International Centre for Olympic Studies: London, ON, Canada, 2010; pp. $163-177$.

22. Yu, Y.; Liu, J. A Comparative Analysis of the Olympic Impact in East Asia: From Japan, South Korea to China. Int. J. Hist. Sport 2011, 28, 2290-2308. [CrossRef]

23. Mangan, J.A.; Kim, H.D.; Cruzc, A.; Kang, G.H. Rivalries: China, Japan and South Korea-Memory, Modernity, Politics, Geopoliticsand Sport. In The Asian Games: Modern Metaphor for The Middle Kingdom Reborn: Political Statement, Cultural Assertion, Social Symbol; Routledge: London, UK; New York, NY, USA, 2017; p. 108.

24. Keohane, O.R.; Nye, S.J., Jr. Power and Interdependence in the Information Age. Foreign Aff. 1998, 77, 81-94. [CrossRef]

25. Mattern, B.J. Why Soft Power isn't so Soft: Representational Force and the Sociolinguistic Construction of Attraction in World Politics. Millenn. J. Int. Stud. 2005, 33, 583-612. [CrossRef]

26. Cull, J.N. The Public Diplomacy of the Modern Olympic Games and China's Soft Power Strategy. In Owning the Olympics: Narratives of the New China; Price, E.M., Dayan, D., Eds.; The University of Michigan Press: Ann Arbor, MI, USA, 2008; pp. 117-144.

27. Manzenreiter, W. The Beijing Games in the Western Imagination of China: The Weak Power of Soft Power. J. Sport Soc. Issues 2010, 34, 29-48. [CrossRef]

28. Grix, J. The Politics of Sports Mega-Events. Political Insight 2012, 3, 4-7. [CrossRef]

29. Murray, S.; Pigman, A.G. Mapping the Relationship between International Sport and Diplomacy. Sport Soc. 2014, 17, 1098-1118. [CrossRef]

30. Rofe, J.S. Sport and Diplomacy: A Global Diplomacy Framework. Dipl. Statecr. 2016, 27, 212-230. [CrossRef]

31. Wang, G. 'Friendship First': China's Sports Diplomacy during the Cold War. J. Am.-East Asian Relat. 2003, 12, 133-153. [CrossRef]

32. Carter, F.T.; Sugden, J. The USA and Sporting Diplomacy: Comparing and Contrasting the Cases of Table Tennis with China and Baseball with Cuba in the 1970s. Int. Relat. 2012, 26, 101-121. [CrossRef]

33. Hocking, B. Rethinking the 'New' Public Diplomacy. In The New Public Diplomacy; Melissen, J., Ed.; Palgrave Macmillan: London, UK, 2005; pp. 28-43.

34. Kramareva, N.; Grix, J. Understanding Public Diplomacy, Nation Branding, and Soft Power in Showcasing Places via Sports Mega-Events. In Marketing Countries, Places, and Place-Associated Brands; Papadopoulos, N., Cleveland, M., Eds.; Edward Elgar Publishing: Cheltenham, UK, 2021; pp. 298-318.

35. BBC. Theresa May's Conservative Conference Speech: Key Quotes. Available online: http://www.bbc.co.uk/news/uk-politics37535527 (accessed on 14 September 2021).

36. The Soft Power 30. Portland Communications. Available online: https://softpower30.com/wp-content/uploads /2019/10/TheSoft-Power-30-Report-2019-1.pdf (accessed on 7 October 2021).

37. Watson, I. South Korea's State-Led Soft Power Strategies: Limits on Inter-Korean Relations. Asian J. Political Sci. 2012, 20, 304-325. [CrossRef]

38. Wilson, L.J. Russia and China Respond to Soft Power: Interpretation and Readaptation of a Western Construct. Politics 2015, 35, 287-300. [CrossRef]

39. Putnam, D.R. Diplomacy and Domestic Politics: The Logic of Two-Level Games. Int. Organ. 1988, 42, 427-460. [CrossRef]

40. Sekaran, U. Research Methods of Business: A Skill-Building Approach, 3rd ed.; John Wiley \& Sons: New York, NY, USA, 2000.

41. Parker, C.; Scott, S.; Geddes, A. Snowball Sampling. In The SAGE Encyclopedia of Social Science Research Methods; E-prints; Gloucester University: Cheltenham, UK, 2019; pp. 1-13.

42. Kook, R.; Ayelet, S.-H.; Yuval, F. Focus Groups and the Collective Construction of Meaning: Listening to Minority Women. Women's Stud. Int. Forum 2019, 72, 87-94. [CrossRef]

43. Braun, V.; Clarke, V. Using Thematic Analysis in Psychology. Qual. Res. Psychol. 2006, 3, 77-101. [CrossRef]

44. Goodwin, M.; Grix, J. Bringing Structures Back in: The 'Governance Narrative', the 'Decentred Approach'and 'Asymmetrical Network Governance'in the Education and Sport Policy Communities. Public Adm. 2011, 89, 537-556. [CrossRef]

45. Grix, J. The Foundations of Research, 3rd ed.; Red Globe Press: London, UK, 2019. 
46. IOC. Seoul 1988 Summer Olympics-Athletes, Medals \& Results. Available online: https://olympics.com/en/olympic-games/ seoul-1988 (accessed on 25 November 2021).

47. Kim, S.H. Civil Society and Democratization in South Korea. In Korean Society: Civil Society, Democracy and the State, 2nd ed.; Armstrong, K.C., Ed.; Routledge: London, UK, 2006; pp. 65-84.

48. Olympedia. Host City Selection. Available online: http:/ /www.olympedia.org/ioc/host_cities (accessed on 25 November 2021).

49. Hahm, C. South Korea's Miraculous Democracy. J. Democr. 2008, 19, 128-142. [CrossRef]

50. Katsiaficas, G.; Na, K.C. South Korean Democracy: Legacy of the Gwangju Uprising; Routledge: New York, NY, USA, 2013.

51. Cho, J.H.; Bairner, A. The Sociocultural Legacy of the 1988 Seoul Olympic Games. Leis. Stud. 2012, 31, 271-289. [CrossRef]

52. Ha, W.Y. Korea Sports in the 1980s and the Seoul Olympic Games of 1988. Ph.D. Thesis, The Pennsylvania State University, State College, PA, USA, 1997.

53. Koh, E. South Korea and the Asian Games: The First Step to the World. Sport Soc. 2005, 8, 468-478. [CrossRef]

54. Cha, V. Role of Sport in International Relations: National Rebirth and Renewal. Asian Econ. Policy Rev. 2016, 11, 139-155.

55. Manheim, B.J. Rites of Passage: The 1988 Seoul Olympics as Public Diplomacy. West. Political Quart. 1990, 43, 279-295. [CrossRef]

56. SOSFO. The History of Seoul Olympic Games XXIVth: Host the Olympic Games; SOSFO Press: Seoul, Korea, 2000.

57. Cha, D.V. Winning Is Not Enough: Sport and Politics in East Asia and Beyond. Int. J. Hist. Sport 2013, 30, 1287-1298. [CrossRef]

58. Trunkos, J.; Heere, B. Sport Diplomacy: A Review of How Sports Can Be Used to Improve International Relationships. In Case Studies in Sport Diplomacy; Esherick, C., Baker, R., Jackson, S., Sam, M., Eds.; Fitness Information Technology, Incorporated: Morgantown, WV, USA, 2017; pp. 1-18.

59. Moenig, U.; Kim, Y.I. The Early Globalization Process of Taekwondo, from the 1950s to 1971. Int. J. Hist. Sport 2021, 37, 1-20. [CrossRef]

60. Porteux, J.N.; Choi, K.J. Hallyu as Sports Diplomacy and Prestige Building. Cult. Empathy 2018, 1, 70-87. [CrossRef]

61. Kang, Y.; Houlihan, B. Sport as a Diplomatic Resource: The Case of South Korea, 1970-2017. Int. J. Sport Policy 2021, 13, 45-63. [CrossRef]

62. Kim, J. Why Does Hallyu Matter? The Significance of the Korean Wave in South Korea. Crit. Stud. Telev. 2007, 2, 47-59. [CrossRef]

63. Longman, J. South Korea and Japan Will Share World Cup. Available online: https://www.nytimes.com/1996/06/01/sports/ soccer-south-korea-and-japan-will-share-world-cup.html (accessed on 30 June 2021).

64. McLaughlin, A. Korea/Japan or Japan/Korea? The Saga of Co-hosting the 2002 Soccer World Cup. J. Hist. Sociol. 2001, 14, 481-507. [CrossRef]

65. Sugden, J.; Tomlinson, A. FIFA and the Contest for World Football: Who Rules the People's Game? 1st ed.; Polity Press: Cambridge, UK, 1998.

66. Hong, E. Elite Sport and Nation-Building in South Korea: South Korea as the Dark Horse in Global Elite Sport. Int. J. Hist. Sport 2011, 28, 977-989. [CrossRef]

67. Butler, O. Getting the Games: Japan, South Korea and the Co-Hosted World Cup. In Japan, Korea and the 2002 World Cup; Horne, J., Manzenreiter, W., Eds.; Routledge: London, UK, 2002; pp. 43-55.

68. Kim, H.J. Kim Young-Sam: Politician Who Ended Military Rule in South Korea. Available online: https://www.independent.co. uk/news/obituaries/kim-youngsam-politician-who-ended-decades-of-military-rule-in-south-korea-and-brought-financialtransparency-a6747476.html (accessed on 30 June 2021).

69. Kim, S.K.; Finch, J. Living with Rhetoric, Living against Rhetoric: Korean Families and the IMF Economic Crisis. Korean Stud. 2002, 26, 120-139. [CrossRef]

70. Joo, Y.M.; Bae, Y.; Eva, K.-N. 2002 FIFA World Cup and the Rebranding of South Korea. In Mega-Events and Mega-Ambitions: South Korea's Rise and the Strategic Use of the Big Four Events; Eva, K.-N., Ed.; Palgrave Macmillan: London, UK, 2017 ; pp. 69-92.

71. Shim, D. Hybridity and the Rise of Korean Popular Culture in Asia. Media Cult. Soc. 2006, 28, 25-44. [CrossRef]

72. Madichie, N.O. Oppan Gangnam Style! A Series of Accidents-Place Branding, Entrepreneurship and Pop Culture. J. Res. Mark. Entrep. 2020, 23, 103-121. [CrossRef]

73. Billboard. Billboard Global Excl. US Chart. Available online: https://www.billboard.com/charts/billboard-global-excl-us/2021 -06-05 (accessed on 29 June 2021).

74. Korea Times. Hallyu Resurges in Japan Amid Diplomatic Rift. Available online: https:/ /www.koreatimes.co.kr/www/art/2020 /07/398_293277.html (accessed on 30 June 2021).

75. Bridges, B. The Seoul Olympics. In The Two Koreas and the Politics of Global Sport; Global Oriental: Kent, UK, $2012 ;$ pp. 65-83.

76. Horne, J.D.; Manzenreiter, W. Accounting for Mega-Events: Forecast and Actual Impacts of the 2002 Football World Cup Finals on the Host Countries Japan/Korea. Int. Rev. Sport Sociol. 2004, 39, 187-203. [CrossRef]

77. Seo, J.E.; New Index for Korea's Hallyu. Korea Joongang Daily. Available online: https://koreajoongangdaily.joins.com/2010/0 3/01/etc/New-index-for-Koreas-hallyu/2917224.html (accessed on 14 September 2021).

78. Dong-a Ilbo. Multimedia at the Tip of Hand Its IMT-2000. Available online: https://www.donga.com/en/Search/article/all/20 020227/221551/1/Multimedia-at-the-Tip-ofHand\%C2\%85-\%C2\%93It\%C2\%92s-IMT-2000\%C2\%94 (accessed on 30 June 2021).

79. Kim, S.; Nam, C. Hallyu Revisited: Challenges and Opportunities for the South Korean Tourism. Asia Pac. J. Tour. Res. 2016, 21, 524-540. [CrossRef]

80. Horne, J. Transnational Sport. Gender, Media, and Global Korea. Sport Soc. 2013, 16, 1218-1220. [CrossRef] 
81. Merkel, U.; Kim, M. Third Time Lucky!? PyeongChang's Bid to Host the 2018 Winter Olympics-Politics, Policy and Practice. Int. J. Hist. Sport. 2011, 28, 2365-2383. [CrossRef]

82. Campbell, C. South Korean President Moon Jae-In Makes One Last Attempt to Heal His Homeland. Available online: https: / / time.com/6075235/moon-jae-in-south-korea-election/ (accessed on 23 September 2021).

83. Merkel, U. The Politics of Sport Diplomacy and Reunification in Divided Korea: One Nation, Two Countries and Three Flags. Int Rev. Sport Sociol. 2008, 289-311. [CrossRef]

84. Madhani, A. Was Hosting the 2018 Winter Olympics Worth the Trouble for South Korea? Available online: https: / / eu.usatoday.com/story/sports / winter-olympics-2018/2018/02/21/hosting-2018-winter-olympics-worth-trouble-southkorea/350410002/ (accessed on 7 October 2021).

85. Wood, J.; Meng, S. The Economic Impacts of the 2018 Winter Olympics. Tour. Econ. 2020, 20, 1-20. [CrossRef]

86. Kim, H.M.; Grix, J. Implementing a Sustainability Legacy Strategy: A Case Study of PyeongChang 2018 Winter Olympic Games. Sustainability 2021, 13, 5141. [CrossRef]

87. Kang, M.; Kim, H. Global and Local Intersection of the 2018 PyeongChang Winter Olympics. Int. J. Jpn. Sociol. 2019, 28, 110-127. [CrossRef]

88. Ki, E.J.; Oh, J.; Kim, C.S. Influence of the Olympic Winter Games PyeongChang 2018 on the Korean Wave: Comparison of Perceptions between Koreans and Americans. Int. J. Popul. Stud. 2020, 6, 15-25. [CrossRef]

89. Kietlinski, R. Japan in the Olympics, the Olympics in Japan. Educ. Asia 2016, 21, 35-40.

90. Chu, M.P. The Pursuit of Regional Geopolitical Aspirations: China's Bids for the Asian Games and the Asian Winter Games since the 1980s. Int. J. Hist. Sport. 2013, 30, 1048-1058. [CrossRef]

91. Yoo, J.H.S. Korea Becomes 5th Nation to Host 4 Major Sporting Events. Available online: https:/ / en.yna.co.kr/view/AEN20180 209014000315 (accessed on 10 July 2021).

92. You, Y.M. ICT Olympics Will Let Everyone Shine. Available online: https://www.koreatimes.co.kr/www/tech/2017/11/133_23 9064.html (accessed on 10 July 2021).

93. Choi, K.J. The Republic of Korea's Public Diplomacy Strategy: History and Current Status; USC Center on Public Diplomacy: Los Angeles, CA, USA, 2019.

94. Dong-a Ilbo. Peace in Motion Should be Followed along with Olympics. Available online: https://www.donga.com/en/Search/ article/all/20180210/1221733/1/Peace-in-Motion-should-be-followed-along-with-Olympics (accessed on 10 July 2021).

95. Martínková, I. Pierre de Coubertin's Vision of the Role of Sport in Peaceful Internationalism. Sport Soc. 2012, 15, 788-797. [CrossRef] 